\title{
The Functional Orientation and Construction Principles of the Embedded System of Moral Education in Colleges and Universities in the "Screen-reading Era"
}

\author{
Ming Yi \\ Faculty of Political Science and Law \\ Zhaoqing University \\ Zhaoqing, China 526061
}

\begin{abstract}
The flourish of information technology and the application and popularization of the network has brought the unprecedented opportunities and challenges for the moral education of colleges and universities. The construction of the comprehensive embedded system is one of the effective means in the educational practice to meet the challenge and improve the effectiveness of the moral education of colleges in the "screenreading era". The basic premise to construct the scientific and reasonable embedded system of moral education in colleges with a strong operability is to clarify its functional orientation and construction principles.
\end{abstract}

Keywords-network application; moral education in colleges; embedded system; function and principle

\section{INTRODUCTION}

According to the 40th China Statistical Report on Internet Development, at present, the number of net citizens in our country has reached 751 million, and the popularizing rate of the internet is $54.3 \%$, and the influence of the information networks on people expands increasingly. Particularly, the popularization of mobile terminals such as smart phones and tablet personal computers enables people to receive the network information at any time, including the fragmented time. The "screen-reading era" among all the people has come. The discourse expression, behavioral patterns and rules of people in the network space increasingly influence the real social space of human. Undoubtedly, the moral education in colleges is one of the fields being influenced tremendously.

The application of network technology provides new means, carriers and opportunities for the development of the moral education in colleges, at the same time bringing new challenges for it. The traditional patterns of the moral education in colleges have no longer been able to completely meet the needs of college students in the "screen-reading era". Therefore, it is urgent to construct the embedded system of the moral education that conforms to the cognitive habits of college students in the "screen-reading era". The embedded system of the moral education in colleges in the "screen-

CLC No.: G41, document code: A, article number: reading era" refers to a systematic structure that conforms to the technological development of the information networks. It is formed by various elements in the process of the moral education in colleges and the composite force of the elements and comprises three links, the discourse content of moral education, the carrier of moral education and the effect appraisal of moral education. The successful construction of the embedded system of the moral education in colleges in the "screen-reading era" depends on the explicit functional orientation and construction principles.

\section{THE FUNCTIONAL ORIENTATION OF THE EMBEDDED SYSTEM OF THE MORAL EDUCATION IN COLLEGES IN THE "SCREEN-READING ERA"}

At present, the relationship between the network and the learning and life of college students is increasingly close. They search information, realize leisure and entertainment and communication as well as make friends through the network. At the same time, they express opinions, represent ideas and relieve their feelings through posting messages on the internet. The complex functions of the network and the characteristics of the behaviors of college students such as the strong curiosity and impulsion have brought new difficulties and challenges for the moral education of college students in daily life. Under this circumstance, an explicit role definition and function exertion of the embedded system of the moral education in colleges have a positive theoretical significance and practical significance on strengthening the effectiveness of the moral education in colleges.

\section{A. The Embedded System of the Moral Education in Colleges} Is the Main Channel to Conduct the Ideological and Political Education on the College Students

College students are the builders and successors of the socialist cause. The ideological and political quality and the moral level of the college students directly determine the specific process of the great practice of socialism with Chinese characteristics even the fate of the socialist cause. Colleges and universities are the main front to cultivate the qualified 
builders and successors of the socialist cause. The embedded system of the moral education in colleges plays an irreplaceable role of the main channel in it. The primary mission of it is to guide and help college students to establish the Marxism world outlook, outlook on life and values through the scientific theories, guiding them to establish and insist on the common ideal of the socialism with Chinese characteristics. Therefore, we shall always persist the education policy of "education orientation and moral education first", striving to explore the new and effective ways to conduct the ideological and political education and the moral character education for college students, especially paying close attention to the effects brought by the application of the information networks. At the meantime, we must take the initiative to welcome the trend of the times, find the problems and positively propose the countermeasures, in order to make the moral education in colleges more pertinent, effective and attractive.

\section{B. The Embedded System of the Moral Education in Colleges Is the Reducing Valve to Reduce the Pressure and Disabuse for College Students}

The dramatic changes of the society caused by the social transformation and the rapid transmission of the changes via the network make the influences of the changes expand imperceptibly. The college students on campus in colleges and universities are inevitably impacted by the social changes. The ideology, value orientation, interest demand and behavioral habits of college students are also diversified increasingly. The pressure from the learning and competition of by college students increases with each passing day. Therefore, the psychological problems of some college students led by it are also prominent increasingly and always become the important factors that disturb their learning and life. Some college students even go to extremes. The popularization and application of the network have provided a virtual communication platform that is free from the influence of such factors as the academic record, social status, economic position and social custom. They can voice their opinions, represent ideas, comment on the society and relieve their feelings through the network. However, the network is not all-purpose. Except for the rational, serious and fair opinions and feelings, the college students will have irrational, joking and impulsive expressions on the network. Without the reasonable guidance, college students will have difficulties in relieving the pressures and confusions. On the contrary, it will bring more questions and anxieties for them. Therefore, the embedded system of the moral education in colleges shall play a role of reducing valve in guiding the feelings of college students on the internet, paying close attention to the appeal and pressure of college students and solving the difficulties and confusions of college students.

\section{The Embedded System of the Moral Education in Colleges Makes the Relationship between College Students and the School and the Family Closer}

The group characteristics and the life characteristics show college students have two distinct characteristics. First, college students have an increasingly strong independent consciousness and have independently thought about and treated problems; second, most of the college students leave parents and attend school, inevitably living in groups. The independent consciousness refers to the consciousness of selfjudgment and self-determination free from the intervention and dominance of others and can guide the behaviors of our own. College students are young people who are full of energy and have an active mind. The independent consciousness of them becomes strong with the increase of experience and knowledge. Besides, some colleges and universities neglect the subjectivity and individuality of students in the teaching arrangement and the daily management and fail to consider the attitudes and feelings of the students, so college students have a psychological inversion. Besides, most of college students rapidly integrate in the college life after getting rid of the emotional dependence of the family. The colorful college life and the pressure of learning competence make many college students lack communication with their parents. The media even report some college students only think of their parents when they need living expenses. The embedded system of the moral education in colleges shall play a role in communicating and explaining between students and the school, between students and their parents. On one hand, the embedded system of the moral education in colleges and universities shall comprehensively explain the policies of the school at the same time reflect the reasonable needs of students to the related department of the school. On the other hand, the communication between students and their parents can be promoted through gratitude education and family affection education, in order to truly let parents satisfied, let the school harmonious and let students understand.

\section{The Embedded System of the Moral Education in Colleges Is the Assistor to Boost the Growth and Success of College Students}

The development of the times has new standards and requirements for the growth and success of the college students, requiring them to have the corresponding knowledge and skills as well as the high ideological and political quality, moral standard and professional quality. Influenced by some negative information in the society and network, at present, some college students have negative ideological trend to some extent, becoming self-centered, utilitarian, too materialistic, pursuing pragmatism and immediate interests and neglecting the positive significance of establishing the ideal and faith, blindly rejecting the well-meaning criticism and warning of others and stubbornly insisting on the ideas and opinions of themselves. They are the negative factors that impede college students to become the qualified and perfect talents. The embedded system of the moral education in colleges shall pay close attention to the ideological situation of college students, encourage their positive aspects and reasonably guide and standardize their negative aspects. It must help college students to correctly realize the positive significance of the improvement of ideological and moral levels in the real life and social competition, and the importance of correctly treating the relationship between mind and body, between individuals and others and the society, guiding them to commit to the nation, integrate in the society and improve themselves, in order to serve as the assistor to boost the growth and success of college students. 


\section{THE CONSTRUCTION PRINCIPLES OF THE EMBEDDED SYSTEM OF THE MORAL EDUCATION IN COLLEGES IN THE "SCREEN-READING ERA"}

In order to make the embedded system of the moral education in colleges and universities in the "screen-reading era", we must always adhere to the correct direction in the construction process, and the basic premise to guarantee the direction is to stick to the basic principles of the construction.

\section{A. The Political Principle}

The political principle means the construction of the embedded system of the moral education in colleges and universities must always follow the correct political direction, with the fundamental goal of cultivating college students to establish the firm ideal and faith. The political principle is the basic principle of the moral education in colleges, centrally embodying the socialist nature of the moral education in colleges. Colleges and universities are the cradle of talent training, assuming the important task of training the qualified socialist builders and successors. The quality of talent training and the existence of the solid political accomplishments and the firm ideal of socialism construction directly concern the prosperity of the socialist cause. Therefore, the construction of the embedded system of the moral education in colleges and universities must have an explicit training direction of socialism, integrate the policies of the party in every link of the moral education, guiding college students to combine the improvement of personal comprehensive quality with the ideal and the Chinese dream of bringing about a great rejuvenation of the Chinese nation.

We should see, with the application and popularization of the internet technology, the channels of the information spreading are increasingly wide and the speed is increasingly fast. The good and bad information intermingled has brought tremendous challenges for the moral education in colleges and universities. Under its influence, college students change in the way of thinking, values and the value orientation, and the moral education in colleges is increasingly difficult. Youthful students are at the period of shaping the world outlook, outlook on life and values. They are extremely sensitive to the rat-fuck information on the network. Because of the limited experience, they neither realize the network has become the important field of the activities of hostile forces nor have the necessary sensitivity and vigilance on the complicated information. They are easily influenced by the information even change their values. The embedded system of the moral education in colleges and universities shall obey the general situation of serving the socialist modernization construction, implementing the important indication of "schools shall always put the persistence of the correct political direction in the first place" and highlighting the direction and target of the education. In the practice of the moral education in colleges and universities, we shall lead the correct political direction through using the socialist core values, reflecting the characteristics of the central theme of era. It is the basic principle we must insist and the method to which we must adhere in the construction practice of the embedded system of the moral education in colleges and universities.

\section{B. The Principle of Subjectivity}

The subjectivity refers to the subjective initiative and creativity of people as the subject in the certain objective activities. The principle of subjectivity mentioned here means we must fully recognize the subjectivity of the college students and respect the dominant position of them in the construction practice of the embedded system of the moral education in colleges and universities.

The establishment of the principle of subjectivity is the inevitable reflection of following the rules of moral education in colleges and universities. The "rules of internalization and externalization" is a basic rule of the moral education. After receiving education, students actively accept the contents and reshape the spiritual realm and then externalize the behaviors and habits of them. The process cannot complete and the real meaning of education will lose without the effective participation and coordination of students.

The flourishing development of the network enormously strengthens the self-awareness, subject consciousness and democracy consciousness of college students. The original education pattern that the students are in the subordinate and passive position is faced with great challenges. The rules and real purpose of the education require us to pay close attention to the needs of the subject at the same time excavate their potential and motivate vigor of them and shape the characters of them on the basis of respecting the subjectivity of individuals. In the principle of subjectivity for the construction of the embedded system of the moral education in colleges and universities, first, the educational idea that people is the purpose must be established. "The educational purpose is the fundamental standard to distinguish the good education from the bad education. In other words, the biggest problem in the education is the establishment of the educational purpose." [1](p39) The fundamental objective of the moral education in colleges and universities is to "cultivate college students" and "help them in the growth". The process requires the manifestation of individuals. The existence value of them shall not be covered by others and the world. The value orientation and the rights of individuals in the grand prospect of the society must be highlighted finally. Therefore, we must pursue the people orientation and attach importance to the true feeling and the mental appeal of college students, making efforts to let the contents of the moral education close to the ideological reality and life reality of students, in order to achieve the fundamental purpose of "cultivate them" and "help them in the growth". Second, the teachers shall have a strong sense of responsibility. In the education process, students yearn for cares and hope to be enlightened by the teachers in a gentle and mild way. Without the strong sense of responsibility, the teachers will have difficulties in seriously and thoroughly understanding the students and cannot take the first step in solving problems. Finally, different methods must be selected according to the specific circumstances of the students. College students are from different places. The different family background, growth environment and thinking habits will inevitably lead to the different learning requirements and needs of them. According to the different requirements, the educational methods corresponding to the psychological characteristics and learning needs are required. Instead of the 
simple infusing, the method must be the active exploration, reflection and critical thinking of the interpersonal relationship, social phenomenon and moral issues.

\section{The Principle of Interaction}

In terms of the behavior characteristics, the moral education in colleges and universities is essentially the interactive activity between two subjects, the teachers and the students. In "teaching" or "learning", the education process will not be completed smoothly without the active involvement and coordination of any side. The moral education in colleges and universities is a science with a strong interactivity. Therefore, the interactivity becomes an important principle of the embedded system of the moral education in colleges and universities. The interaction in the moral education in colleges and universities essentially means fully making use of the various media and platforms and letting college students practice consciously on the basis of identity acceptance and internalization improvement through information transfer and communication, finally realizing the synergetic cognition and the spiritual integration between the two subjects of teachers and students.

The network has provided a great convenience for the communication range and horizon of people. It has changed the ways and habits of communication of people to a large extent. Because of its characteristic of anonymity, people can freely enjoy the happiness of communication only through connecting with the network. The way is extremely appealing to the young college students who have an active mind and a strong curiosity. The moral education in colleges and universities refers to the education activity of "cultivate people" and "help people in the growth". We shall notice the influence of the "screen-reading era" on the moral education in colleges and universities, changing the original unidirectional, boring, homiletic and too serious characteristics and highlight the characteristic of communicative interaction.

First, we should create a relaxed and lively environment for interaction. Teachers in the moral education in colleges and universities shall change the unidirectional, homiletic and too serious education process step by step, letting the ways of transmitting the educational information and the contents present the vitality of humanity. They must let the expression of the moral education more popular, and turn the moral education into the information exchange and emotion communication of living and humanization, instead of the boring accumulation of vocabularies. Second, the relaxed and lively methods of interaction must be explored and applied. The teachers of the moral education in colleges and universities inevitably have difference with the college students in roles, abilities and experience. "The whole superstructure formed by the different emotions with a unique manifestation, fantasy, modes of thought and outlook on life stands on the social survival condition."[2] (p611) In the construction of the embedded system of the moral education in colleges and universities, we shall rationally treat the difference and change the traditional unidirectional teaching method that "you listen to me and do what I say", highlighting the values and dignity of students in the bilateral interaction of "sincerity, democracy and equality". In order to make the educational methods relaxed and lively, teachers shall refer to the good network cases and the characteristics of expressing network discourse to achieve the communication and spiritual communication. Students will definitely be influenced by the sincere, understandable and respectable attitudes of teachers, in order to realize the exchange of cognition and spiritual integration of subjects.

\section{CONCLUSION}

To sum up, we shall pay high attention to the functional orientation and the construction principles of the embedded system of the moral education in colleges and universities in the "screen-reading era" and constantly lead the interaction between the educational process and the network area through the socialist core values, laying a solid theoretical foundation for realizing the Chinese dream of the great rejuvenation of the Chinese nation and the development of college students in life.

\section{REFERENCES}

[1] Zhou Haobo. Philosophy of Education [M], Beijing: People's Publishing House, 1999.

[2] Marx, Engels, An Anthology of Marx and Engels: the First Volume [M], Beijing: People's Publishing House, 1995

[3] Luo Yuting, Guo Li. Spiritual Interaction: The Nature of the Interaction of the Ideological and Political Education [J], Teaching and Research, 2014, (1).

[4] Cao Qingyan. Philosophical Survey of the Research on the Purpose of the Ideological and Political Education [J], Ideological and Theoretical Education, 2011, (11).

[5] Liu Jianhua. The Role Play and Function Exertion of the Internet Public Opinion on Campus [J], Academic Forum, 2009, (4). 